\title{
Antioxidant and Hypoglycemic Activities of Clausena anisata (Willd.) Hook F. Ex Benth. Root Mediated Synthesized Sil- ver Nanoparticles
}

\author{
Arsia Tarnam Yakoob ${ }^{1}$, Nargis Begum Tajuddin', Muhammad llyas Mohammed Hussain², Shilu Mathew ${ }^{1}$, Arc- \\ hunan Govindarajü and Ishtiaq Qadri ${ }^{3 *}$
}

\section{Arsia Tarnam Yakoob ${ }^{1}$, Nargis Begum Tajuddin', Muhammad Ilyas Mohammed Hussain ${ }^{2}$, Shilu Mathew' ${ }^{1}$, Ishtiaq Qadri ${ }^{3 *}$ and Archunan Govindaraju ${ }^{4}$}

'Department Of Biotechnology, Jamal Mohamed College (Autonomous), Trichy-20, INDIA.

2Department Of Botany, Jamal Mohamed College (Autonomous), Trichy-20, INDIA.

${ }^{3}$ Division of Virology, Department of Biological Sciences, Faculty of Science, King Abdulaziz University, JEDDAH, KSA ${ }^{4}$ Center For Pheromone Technology, Department Of Animal Science, Bharathidasan University

Tiruchirappalli-620 024, INDIA.

Correspondence

Prof.Ishtiaq Qadri

Division of Virology, Department of Biological Sciences, Faculty of Science, King Abdulaziz University, Jeddah Jeddah,K.S.A

Mobile 00966500665783

Email: ishtiaqmq@gmail.com

DOI : 10.5530/pj.2016.6.10

Article Available online

http://www.phcogj.com/v8/i6

Copyright

C 2016 Phcog.Net. This is an openaccess article distributed under the terms of the Creative Commons Attribution 4.0 International license.

\begin{abstract}
The present study was carried out to examine the hypoglycemic effect of Silver Nanoparticles (SNPs) using ethanolic root extract of Clausena anisata (Willd.) Hook. f. ex Benth. A cost effective and eco friendly technique for green synthesis of SNPs from $1 \mathrm{mM}$ $\mathrm{AgNO}_{3}$ solution through the root extract was carried out. The biosynthesized SNPs were characterized using UV spectrophotometry, Field Emission Scanning Electron Microscopy (FESEM), X-ray Diffraction analysis (XRD), Energy Dispersive Spectroscopy (EDS) and Fourier transform infra-red (FTIR) spectrometry. DPPH assay was done to determine the antioxidant activity and for in vitro hypoglycemic activity glucose uptake by yeast cells, alpha amylase inhibition assay, adsorption capacity and glucose diffusion assay was performed. The SNPs of ethanolic root extract were found to be spherical in shape and up to $32.75 \mathrm{~nm}$ average in size. They showed alpha amylase inhibitory activity of $83.60 \%$ at $500 \mu \mathrm{g} / \mathrm{ml}$. The glucose uptake by yeast cells was found to increase with an increase in concentration. The maximum glucose uptake was found to be $69.51 \%$ at $10 \mathrm{mM}$ concentration. The molar concentration of glucose was directly proportional to the glucose binding capacity of extracts. The rate of glucose diffusion across the membrane was found to increase from 30 to 180 minutes. The DPPH scavenging activity was found to be potent $(74.07 \%)$ at $500 \mu \mathrm{g} / \mathrm{ml}$. The hypoglycemic effect exhibited by the SNPs was revealed by simple in vitro model of yeast cells, mediated by glucose adsorption, increasing glucose diffusion and glucose transport across the cell membrane. Key words: C. anisata, Silvernanoparticles, Diabetes, Antioxidant activity, Glucose and Silver nitrate.
\end{abstract}

\section{INTRODUCTION}

Diabetes Mellitus is a multifactorial metabolic disease characterized by hyperglycemia, including abnormal carbohydrate, fat and protein metabolism leading to several complications and hence needs a combined therapeutic approach. ${ }^{1}$ Insulin injections are given in case of total lack of insulin; the post prandial hyperglycemia is managed at digestive level by using acarbose, miglitol and voglibose drugs. ${ }^{2}$ In India, the number of people affected with diabetes is expected to rise from 171 million in 2000 to 366 million by $2030{ }^{3}$ Out of the two major types of diabetes, type II diabetes is more prevalent and mainly due to the loss of pancreatic $\beta$-cell function, which results in insulin resistance. The regeneration or stabilization of $\beta$-cell must occur, in order to prevent the loss of $\beta$-cells. ${ }^{4}$ Even though there are several drugs to tightly regulate blood glucose, to reduce microvascular and macrovascular complications, the main undesirable effects of this anti-diabetic drug that are currently available are brain damage, swelling, erythema, abdominal pain, weight gain, metallic taste, vitamin $B_{12}$ deficiency, heart failure and gastro intestinal disturbances. Due to these side effects of oral hypoglycemic agents and oxidative stress in complicating diabetes, ${ }^{5}$ there is growing interest in herbal remedy for the treatment of type II diabetes mellitus and oxidative stress.

In India, more than 150 plants of different families were reported to have hypoglycemic activity. Among them,Clausena anisata (Willd.) Hook f. ex. Benth, is one which belongs to the family Rutaceae, ${ }^{6}$ is represented by about 20 species in India and are used traditionally for the treatment of several ailments such as rheumatism, cold, arthritis, analgesic, heart disorder, hepatic disease, antiseptic, anthelmintic, gastro intestinal disorders, fever, headache, sinusitis, wounds, sprains, fractures, toothache, mouth infection, stimulate insulin secretion ${ }^{7}$ and convulsions. ${ }^{8}$

As per traditional claims, Clausena anisata was reported to possess insulin stimulating activity. Even though the plant is explored for antidiabetic activity
Cite this article : Yakoob AT, Tajuddin NB, Hussain MIM, Mathew S, Govindaraju A, Qadri I. Antioxidant and Hypoglycemic Activities of Clausena anisata (Willd.) Hook F. Ex Benth. Root Mediated Synthesized Silver Nanoparticles. Pharmacognosy Journal. 2016;8(6):579-586. 
but no reports are available on the mechanisms of their hypoglycemic effects. Hence based on the traditional indication, the present study was aimed to evaluate their effects on glucose adsorption, diffusion and glucose uptake by yeast cells using in vitro techniques that will elucidate the plausible mechanism of its activity. The antioxidant and hypoglycemic activity of ethanolic SNP root extracts of $C$. anisata has not been reported till date under in vitro conditions. Evaluating their potential will provide an effective utilization as therapeutic agents for Type II diabetes.

\section{MATERIALS AND METHODS}

\section{Procurement of plant material}

Fresh roots of Clausena anisata (Figure 1) were procured during the months of October and November (2013) from Manamettupatti of Viralimalai Taluk (Pudukottai District, Tamil nadu). The plant was identified by Rev. Fr. Dr. S. John Britto, Director, The Rapinat Herbarium and Centre for Molecular Systematics of St. Joseph's College, Tiruchirappalli-620 002 and authenticated as Clausena anisata (Willd.) Hook. f. ex Benth. Vouchered herbarium by specimen No: LB NSD 001.

\section{Preparation of plant extract and SNPs}

$10 \mathrm{~g}$ of shade dried root powder was macerated at $35^{\circ} \mathrm{C}$ to $37^{\circ} \mathrm{C}$; three to five times for 15-20 hrs with $100 \mathrm{ml}$ of ethanol in an Erlenmeyer flask (500 $\mathrm{ml}$ ). Then the extract was centrifuged, filtered using Whatmann No. 1 filter paper and safely stored. The biosynthesis of SNP was carried out as outlined by the method. ${ }^{9}$

\section{Optimization and synthesis of SNPs}

$1 \mathrm{ml}, 3 \mathrm{ml}$ and $5 \mathrm{ml}$ of ethanolic rootextracts were taken in a separate conical flask and to this $10 \mathrm{ml}$ of $1 \mathrm{mMAgNO}_{3}$ solution was added with constant stirring and were exposed under different conditions like sunlight radiation, direct boiling, microwave irradiation (10s on, 10s off) to prevent overheating and aggregation of metals, UV irradiation and room temperature (Figure 2). The color change of the root extract was checked periodically and the color changes from beige to dark brown indicate the synthesis of SNPs from the roots.

\section{Production and recovery of SNPs}

For bulk production, $10 \mathrm{ml}$ of root extract in $100 \mathrm{ml}$ of $1 \mathrm{mM} \mathrm{AgNO}$ was prepared. After bio reduction, the extract consisting of SNPs was subjected to centrifugation at $10,000 \mathrm{rpm}$ for $20 \mathrm{~min}$, and the supernatant was discarded. To the pellet, $0.1 \mathrm{ml}$ of toluene water was added, air dried, lyophilized and stored for further characterization.

\section{CHARACTERIZATION STUDIES}

The biosynthesized SNPs were characterized by the following methods:

\section{Visual Observation}

A change of color from beige to reddish brown was periodically noticed in the root extractsexposed to different conditions as illustrated earlier.

\section{UV- Vis Spectrophotometric analysis}

The formation of SNPs was confirmed and was studied using the spectral analysis. The UV spectra of the biosynthesized SNPs were recorded using Lambda 35, Perkin Elmer Spectrophotometer by continuous scanning from $190 \mathrm{~nm}$ to $1100 \mathrm{~nm}$ and distilled water was used as the reference.

Fourier Transform Infra Red Spectroscopy Analysis (FTIR) The functional groups in the biosynthesized SNPs were analyzed by FTIR spectroscopy. These measurements were carried using a Perkin Elmer spectrum RX I FTIR instrument with a wavelength range of $4000 \mathrm{~cm}^{-1}$ to $400 \mathrm{~cm}^{-1}$. The results were compared for shift in functional peaks.

\section{Field Emission Scanning Electron Microscopy (FESEM)}

FESEM was used to characterize the mean particle size, morphology of the SNPs. A small drop of biosynthesized SNPs solution was placed on glass slide and allowed to dry. The samples were analyzed by using FEI Quanta 200 FEG machine at a low vacuum in the range $10-20 \mathrm{Kv}$.

\section{Energy Dispersive Spectroscopy (EDS)}

The elemental composition of the synthesized SNPs was analyzed with energy dispersive spectroscopy coupled to scanning electron microscope.

\section{X-ray Diffraction Analysis (XRD)}

The structure and composition of SNP were studied by XRD (XPERTPRO Machine). The data was collected in the $2 \theta$ range.

\section{Determination of antioxidant activity (DPPH assay)}

The antioxidant activity of the SNPs was evaluated by DPPH radical scavenging assay. ${ }^{10}$ SNPs of different concentration ranging from 100 $\mu \mathrm{g} / \mathrm{ml}-500 \mu \mathrm{g} / \mathrm{ml}$ were prepared. To this, DPPH at a concentration of $0.1 \mathrm{mM}$ was added and incubated at room temperature for $30 \mathrm{~min}$. The absorbance was recorded at $517 \mathrm{~nm}$. The control sample was carried out without adding leaf extract. Ascorbic acid was used as a standard control. The DPPH free radical scavenging activity was calculated using the following formula:

$$
\% \text { Scavenging }=\frac{\mathrm{Abs}_{\text {control }}-\mathrm{Abs}_{\text {test sample }}}{\mathrm{Abs} \mathrm{s}_{\text {control }}} \times 100
$$

\section{In vitro Hypoglycemic Activity}

\section{Alpha-amylase inhibition assay}

The alpha-amylase inhibitory activity was carried out using a carbose as the reference compound based on the spectro photometric assay. ${ }^{11}$ The SNPs at a concentration of $100-500 \mu \mathrm{g} / \mathrm{ml}$ was prepared by dissolving in DMSO. $3.246 \mathrm{mg}$ of $\alpha$-amylase $(0.5 \mathrm{U} / \mathrm{ml}$ ) (EC 3.2.1.1) was dissolved in $100 \mathrm{ml}$ of $20 \mathrm{mM}$ phosphate buffer $\left(\mathrm{p}^{\mathrm{H}} 6.7\right)$ containing $6.5 \mathrm{mM}$ sodium chloride. Seven duplicate test samples including the blank and control were prepared. In each sample, $250 \mu \mathrm{l}$ of the enzyme was added with $100 \mu \mathrm{l}$ of SNP extracts of different concentrations except blank and were incubated in a water bath at $37^{\circ} \mathrm{C}$ for $20 \mathrm{~min}$ with constant stirring in a vortex. After incubation, $250 \mu \mathrm{l}$ of starch $(0.5 \% \mathrm{w} / \mathrm{v}$ starch dissolved in $20 \mathrm{mM}$ phosphate buffer, $\mathrm{p}^{\mathrm{H}}$ 6.7) was transferred into each sample in the test tube to initiate the reaction. It was again incubated at $37^{\circ} \mathrm{C}$ for $15 \mathrm{~min}$ after vortexing. DNS reagent of $2 \mathrm{ml}$ was added and strirred in a vortex. Later it was boiled in water bath at $100^{\circ} \mathrm{C}$ for $10 \mathrm{~min}$, thereafter the mixture was cooled downand the absorbance was measured at $540 \mathrm{~nm}$ and control sample was carried out without adding the leaf extract.

Percentageinhibition was calculated by the expression:

$$
\% \text { Inhibition }=100-\frac{\text { Mean product in sample }}{\text { Mean product in control }} \times 100
$$

\section{Glucose uptake by yeast cells}

Commercial baker's yeast was prepared ${ }^{12}$ in distilled water by repeated centrifugation at $21000 \mathrm{rpm}$ for 5 mins until the supernatantwas clear. The $10 \%(\mathrm{v} / \mathrm{v})$ concentration of yeast suspensionwas prepared in distilled 
water. SNP extracts at concerntration of $100 \mu \mathrm{g}-2 \mathrm{mg}$ were added separately to $1 \mathrm{ml}$ of glucose solution $(5,10,25 \mathrm{mmol} / \mathrm{L})$ and incubated for 10 minutes at $37^{\circ} \mathrm{C}$. To this, $100 \mu \mathrm{L}$ of yeast suspension was added to start the reaction and vortexed. Then it was incubated at $37^{\circ} \mathrm{C}$ for $60 \mathrm{~min}$. After $60 \mathrm{~min}$, at $3800 \mathrm{r} / \mathrm{min}$ for $5 \mathrm{~min}$ the tubes were centrifuged and the glucose present in the supernatant was estimated at $540 \mathrm{~nm}^{13}$

The percentage of glucose uptake by yeast cells was calculated using the formula:

$$
\text { Percent increase in glucose uptake }(\%)=\frac{\mathrm{Abs}_{\text {control }}-\mathrm{Abs}_{\text {sample }}}{A b s_{\text {control }}} \times 100
$$

Where, Abs control and Abs sampleis the absorbance of the control reaction (without the addition of SNPs) and test sample respectively.

\section{Glucose Diffusion Assay}

$1 \mathrm{~mL}$ of glucose solution at a concentration of $25 \mathrm{mmol} / \mathrm{L}$, was prepared by dissolving in $0.15 \mathrm{M} \mathrm{NaCl}^{14}$ and $1 \%$ of SNPs were dialyzed in two separate dialysis bags for control and test sample. Then the dialysis membrane was tied at both ends and immersed in a separate beaker containing $10 \mathrm{ml}$ of distilled water and $40 \mathrm{ml} 0.15 \mathrm{M} \mathrm{NaCl}$. For control, SNP extract was not added. The beakers were incubated at room temperature. The glucose content in the dialysate was determined at 30,60, 120 and 180 min by DNS method. ${ }^{15}$ Glucose Dialysis Retardation Index (GDRI) was calculated by using the formula:

$$
\operatorname{GDRI}(\%)=100-\frac{\text { Glucose content }(\text { with sample } \mathrm{mg} / \mathrm{dL})}{\text { Glucose content }(\text { without sample } \mathrm{mg} / \mathrm{dL})} \times 100
$$

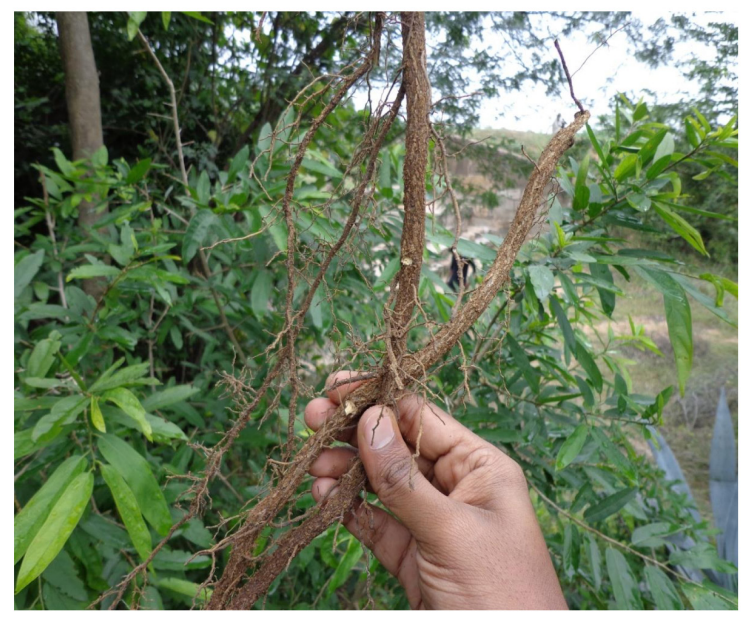

Figure 1: Roots of $C$. anisata collected from Manamettupatti.

\section{Dinitrosalicylic colorimetric method (DNS)}

After incubation, $250 \mu \mathrm{l}$ of the starch $(0.5 \% \mathrm{w} / \mathrm{v}$ of starch was dissolved in $20 \mathrm{mM}$ phosphate buffer $\left.\left(\mathrm{p}^{\mathrm{H}} 6.7\right)\right)$ was transferred into each test tube carrying glucose content of dialysate at 30,60,120 and 180 mins. The vortexed mixture was incubated at $37^{\circ} \mathrm{C}$ for 15 mins. DNS reagent of 2 $\mathrm{ml}$ was added, stirred in a vortex and boiled in water bath at $100^{\circ} \mathrm{C}$ for 10 mins. The mixture was cooled and the absorbance was measured at $540 \mathrm{~nm}$.

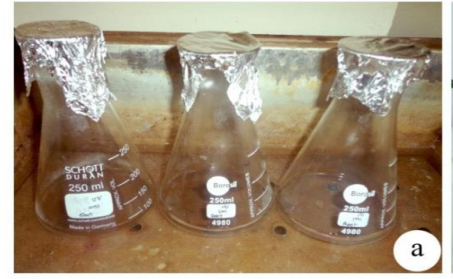

Water bath

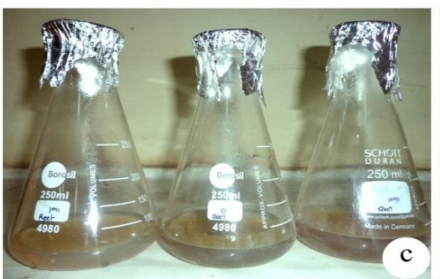

Microwave irradiation (10secs)

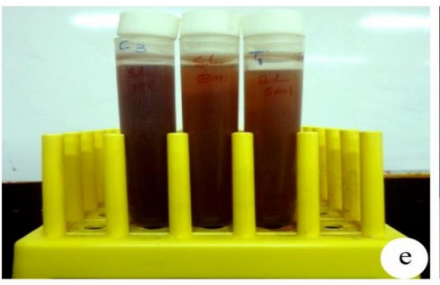

Sunlight irradiation

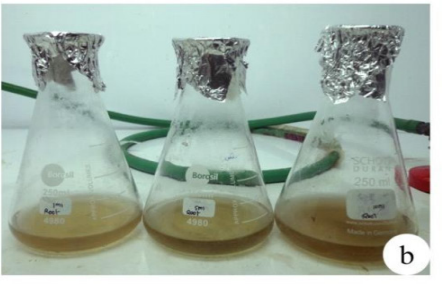

UV Irradiation

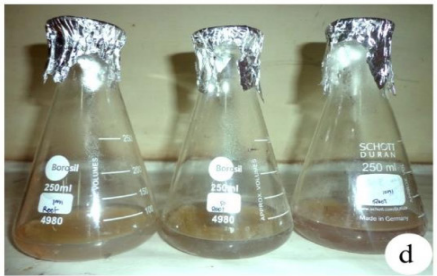

Microwave irradiation (50secs)

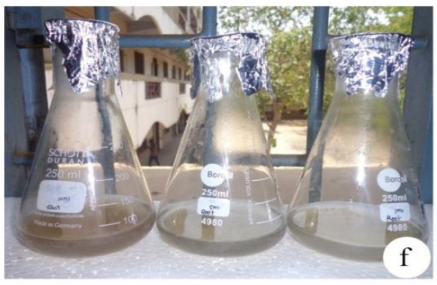

Room temperature
Figure 2: Optimization and synthesis of SNP using C. anisata ethanolic root extract.

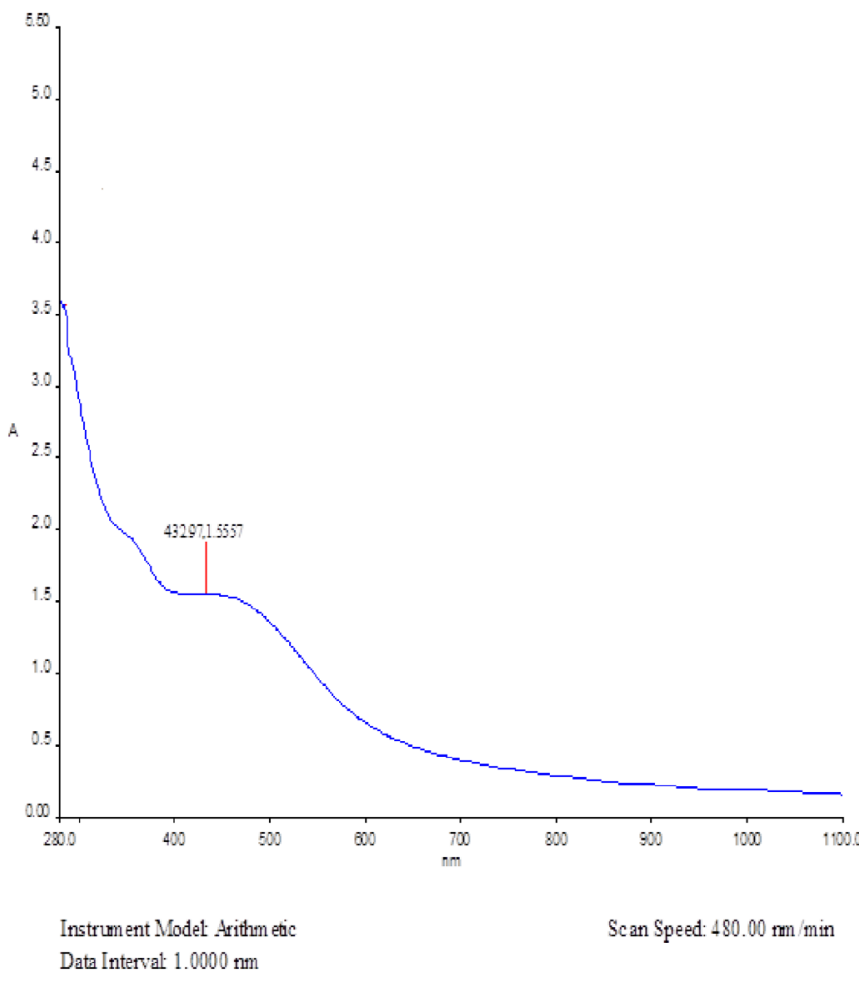

Figure 3: UV-Vis profile dor ethanolic SNP root extracts of $C$. anisata. 
Table 1: FTIR spectral peak values and functional groups obtained for the SNP root extract of Clausena anisata

\begin{tabular}{cccc}
\hline S.No & Peak value $\mathrm{cm}^{-1}$ & Bond & Functional groups \\
\hline 1 & 663.20 & C-H bend & Alkynes \\
2 & 774.15 & C-Cl Stretch & Alkyl halide \\
3 & 1015.96 & C-O stretch & Alcohol \\
4 & 1361.75 & N-O symmetric stretch & Nitro compounds \\
5 & 1630.84 & $\mathrm{RNH}_{2}$ & Amines \\
7 & 2832.62 & $\mathrm{H}-\mathrm{C}=\mathrm{O}$ & Aldehyde \\
8 & 3432.97 & $\mathrm{~N}-\mathrm{H}$ stretch & Amine, amide \\
\hline
\end{tabular}

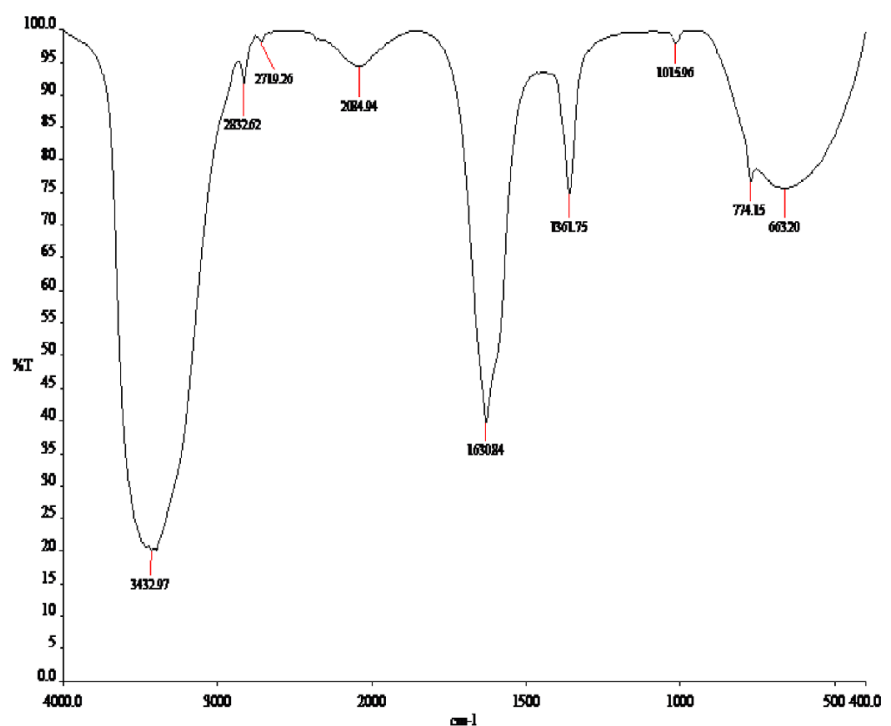

Figure 4: FTIR spectrum of $C$. anisata ethanolic SNP root extracts.

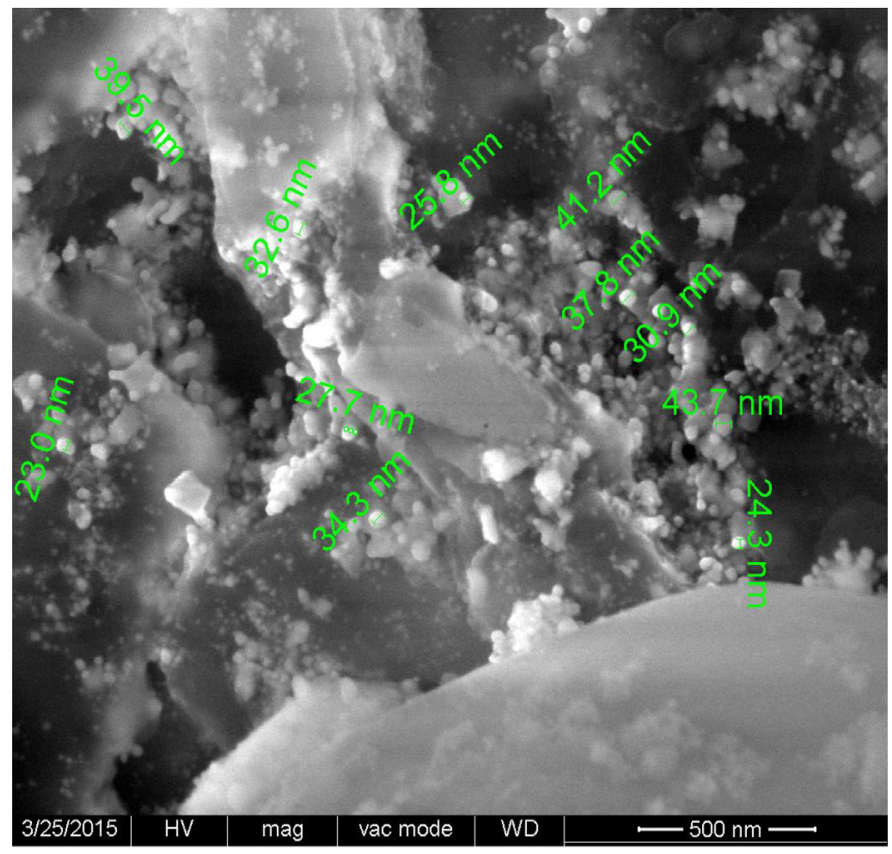

Figure 5: SEM analysis of $C$. anisata SNP root extract.

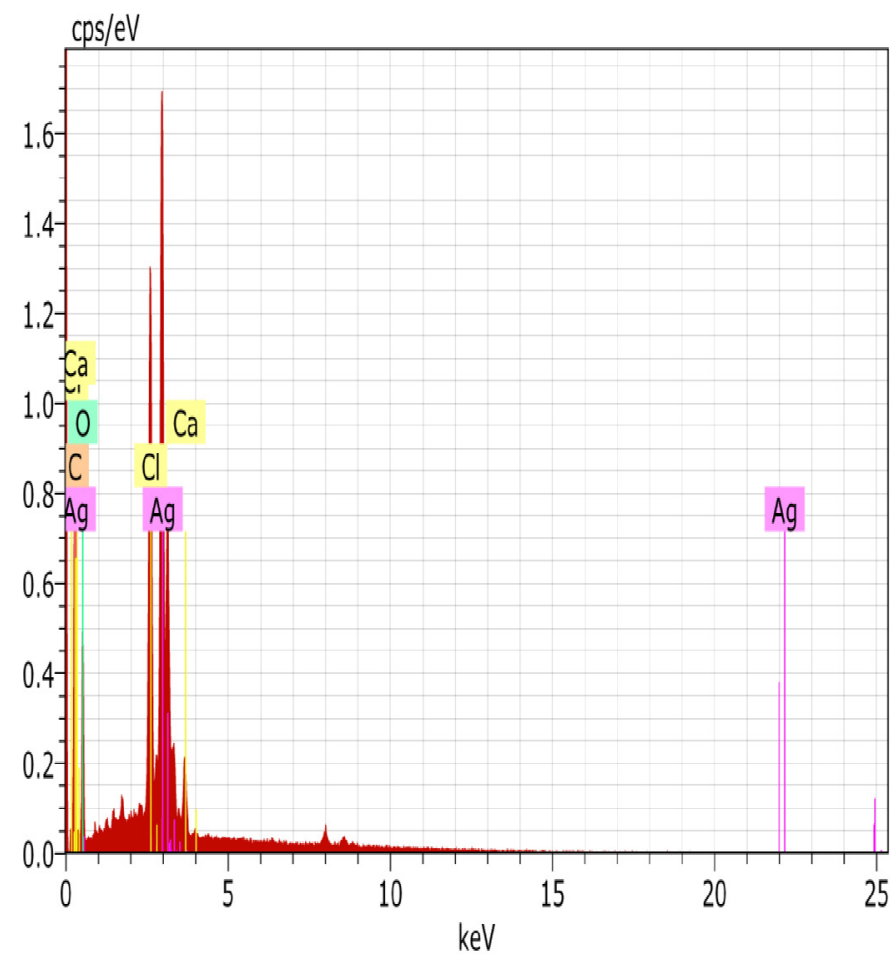

Figure 6: EDS analysis of ethanolic root extract of $C$. anisata.

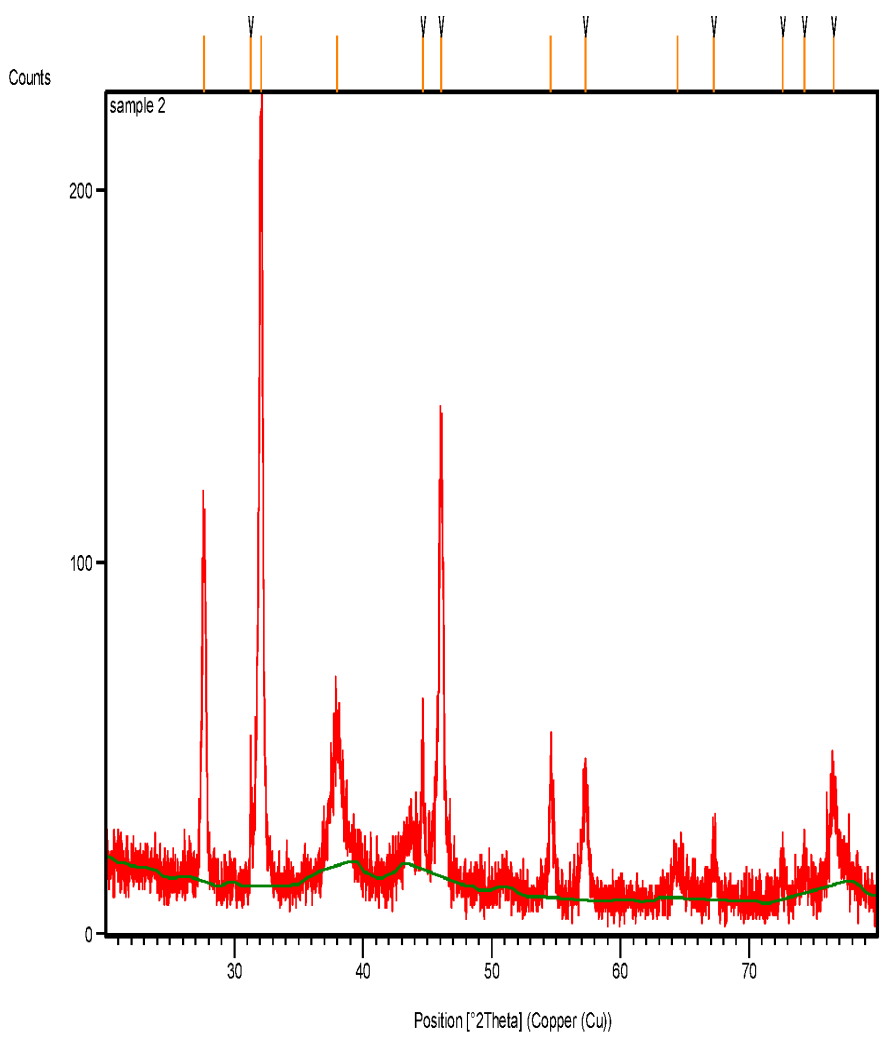

Figure 7: XRD analysis of $C$. anisata SNP root extract. 


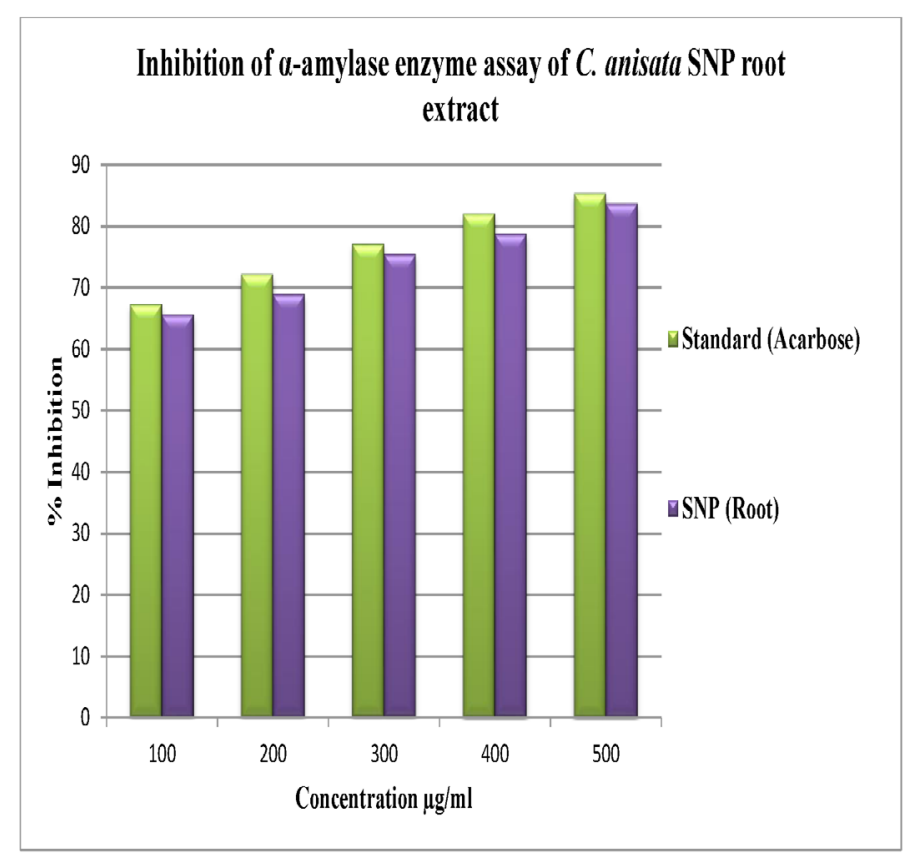

Figure 8: Percentage inhibition of a-amylase enzyme assay of $C$. anisata SNP root extract.
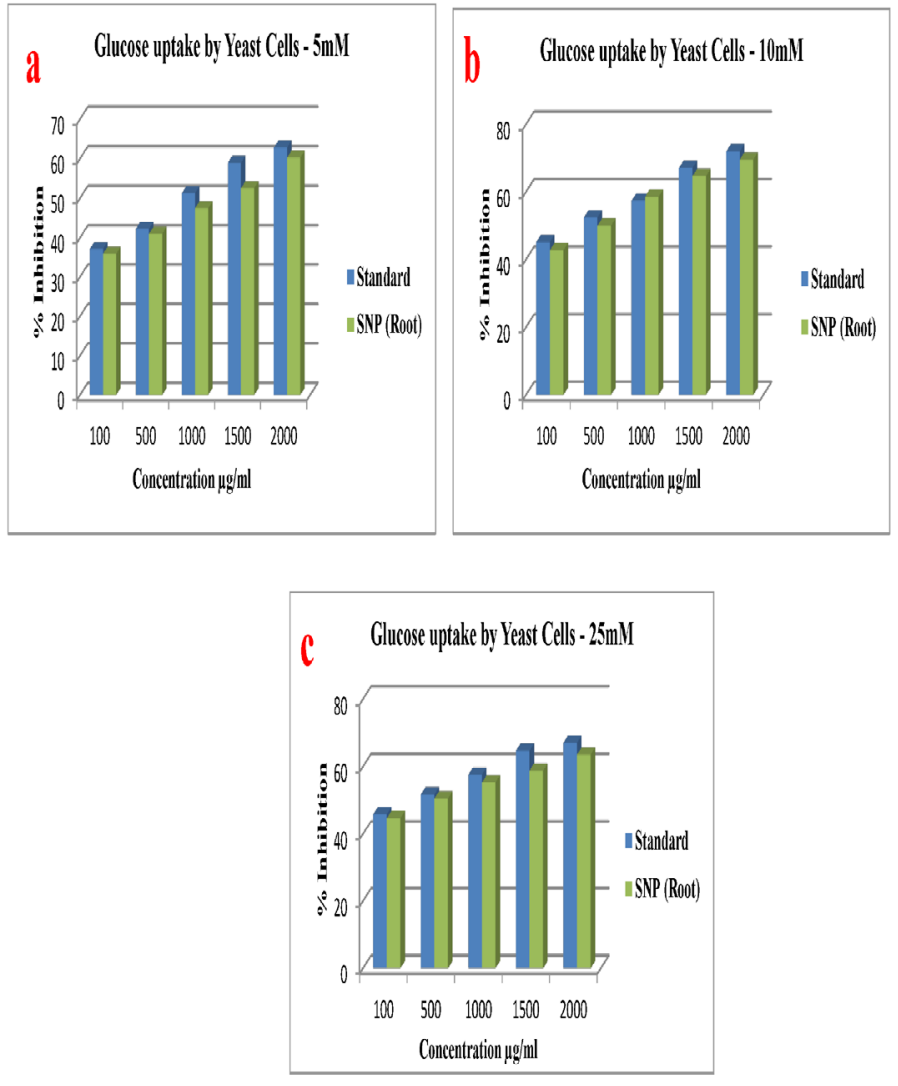

Figure 9: Glucose uptake by yeast cells in presence of $C$. anisata SNP root extract a) $5 \mathrm{mM} \mathrm{b)} 10 \mathrm{mM}$ c) $25 \mathrm{mM}$.
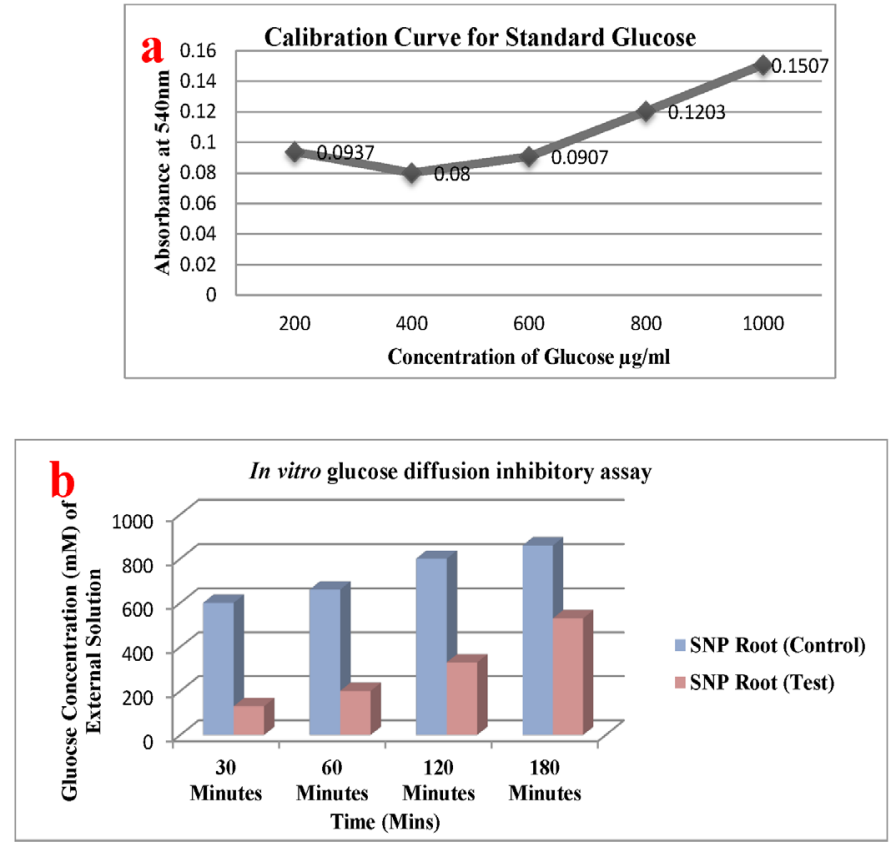

Figure 10: a) Standard calibration curve for glucose estimation b) Glucose concentration in the dialysate in presence of $C$. anisata extracts.
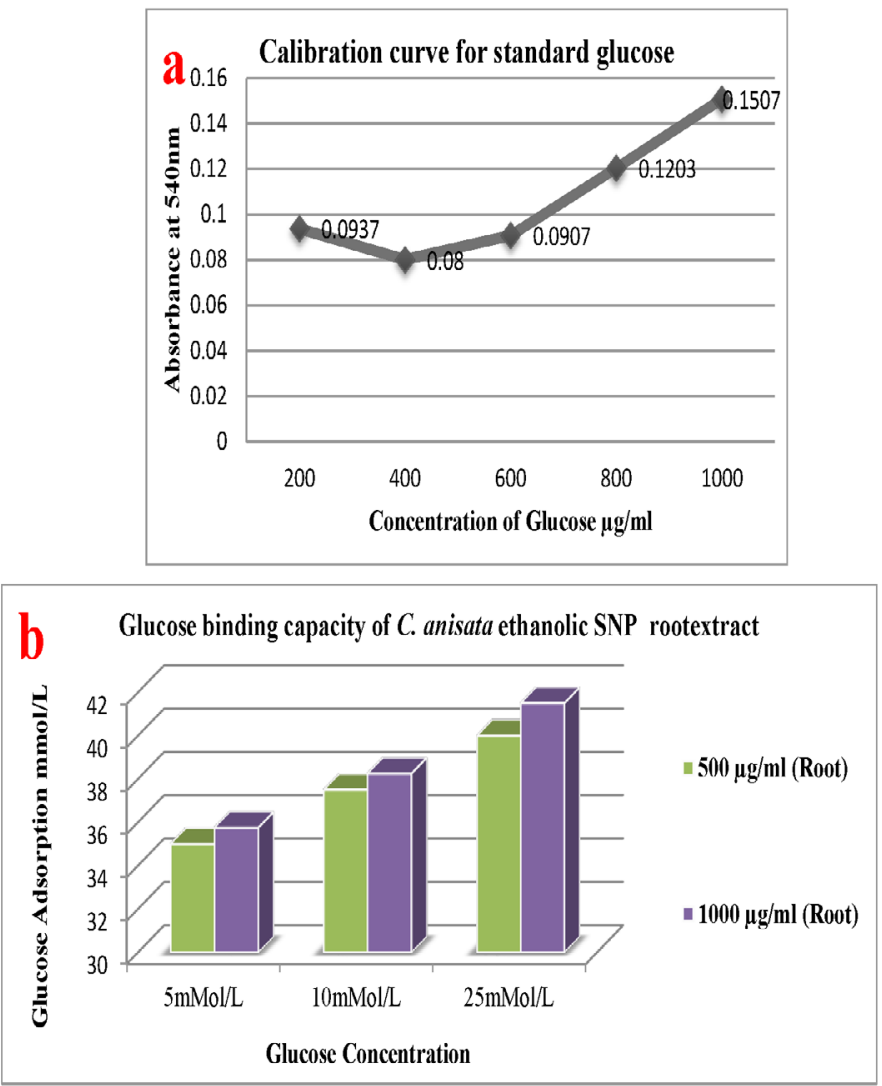

Figure 11: Standard calibration curve for glucose estimation b) SNP root extract. 


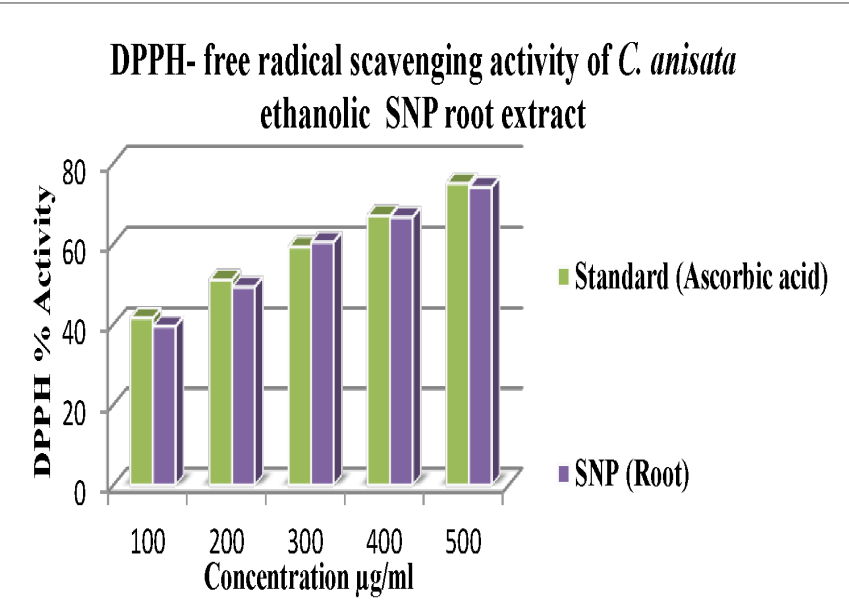

Figure 12: DPPH percentage scavenging activity of $C$. anisata SNP root extracts.

\section{Glucose Adsorption Capacity}

SNP at a concentration of $1 \%$ was added to $25 \mathrm{~mL}$ of 5,10 , and $25 \mathrm{~mm}$ $\mathrm{ol} / \mathrm{L}$ glucose solution in a four separate experiments. The content was vortexed and incubated in water bath at $37^{\circ} \mathrm{C}$ for $6 \mathrm{hrs}$ and centrifuged at $4800 \mathrm{rpm} / \mathrm{mins}$ for 20 mins. ${ }^{16}$ The glucose content in the supernatant was determined at $540 \mathrm{~nm}$. The bound glucose concentration was calculated using the formula:

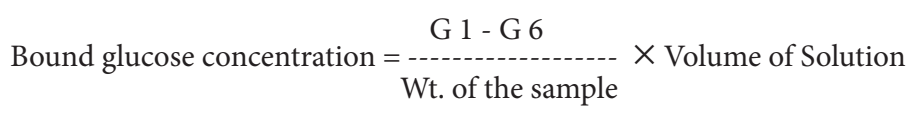

$\mathrm{G}_{1}$ is the glucose concentration at $0^{\text {th }}$ hour

$\mathrm{G}_{6}$ is the glucose concentration after 6 hours

\section{Statistical analysis}

The results were expressed as the mean \pm standard deviation from three independent experiments with triplicates. One way analysis of variance (ANOVA) was performed followed by Tukey's test. $\mathrm{P}<0.05$ was considered statistically significant.

\section{RESULTS AND DISCUSSION}

Among various concentration and methods used, $1 \mathrm{ml}$ of extract exposed under room temperature was found to be very effective and showed maximum synthesis ofnanoparticles. In this study it was observed that there was visible color change when silver nitrate was added to the root extract. Initially the leaf extract was beige in color and after the addition of silver nitrate; it was turned into brown in colour (Figure 2e). The ethanolic root extract of C. anisata reduced silver ions into SNP was evidenced by visual colour change. This indicated the formation of SNPs due to excitation of surface Plasmon vibration in silver nanoparticles.

\section{UV - Vis spectral analysis of SNPs}

The color change of root ethanolic extracts of C. anisata arised due to the excitation of SPR with the SNPs. The SPR of SNPs produced a peak centred near to $432.97 \mathrm{~nm}$ (Figure 3) for root, with absorption 1.5557 respectively. These results indicated the successful conversion of silver nitrate $\left(\mathrm{Ag}^{+}\right)$to Silver $\left(\mathrm{Ag}^{0}\right)$. The SPR band is due to the free electrons in the conduction band due to small particle size. ${ }^{17}$ Due to the combination of proteins, amino acids, enzymes, polysaccharides, alkaloids, tannins, phenolics, saponins and terpenoids may be responsible for the reduction and stabilization of silver ions. ${ }^{18}$ Proteins that have stronger binding affinity to SNPs will increase the stability of synthesized NPs. ${ }^{19}$

The absorbance peaks obtained for C. anisata root extracts was in line with $^{20}$ who investigated the synthesis of SNPs from Musa balbisiana, Azadirachta indica and Ocimum tenuiflorum extracts, which possessed a characteristic absorption peaked in the range of $425-475 \mathrm{~nm}$ confirmed the reduction of silver ions due to SPR.

\section{FTIR Spectrum}

FTIR analysis was used to identify the functional groups of the active components in the extracts that are responsible for reducing and capping the synthesized SNPs. Eight IR bands were identified for SNP root extracts which was tabulated. The absorption peak of $1630.84 \mathrm{~cm}^{-1}$ for SNP root in the infrared region of the electromagnetic spectrum exhibited the binding of amide linkage with SNPs that may be assigned to the carbonyl stretch in proteins and clearly indicated the presence of protein as capping agent for SNPs. FTIR spectral data for the biosynthesized SNP root extract were attributed to the N-H stretch at $3432.97 \mathrm{~cm}^{-1}$, $\mathrm{H}-\mathrm{C}=\mathrm{O}$ stretch exists in the region of $2832.62 \mathrm{~cm}^{-1}$, peaks at $663.20 \mathrm{~cm}^{-1}$, $774.15 \mathrm{~cm}^{-1}, 1015.96 \mathrm{~cm}^{-1}, 1361.75 \mathrm{~cm}^{-1}$ and $1630.84 \mathrm{~cm}^{-1}$ can be assigned to $\mathrm{C}-\mathrm{H}$ bend, $\mathrm{C}-\mathrm{Cl}$ stretch, $\mathrm{C}-\mathrm{O}$ stretch, $\mathrm{N}-\mathrm{O}$ symmetric stretch and $\mathrm{RNH}_{2}$ stretch (Figure4). Earlier report suggested that peaks denoting -C-N stretching vibrations of amine, C-O-C, ether linkage, -C-O-, germinal methyl, $-\mathrm{C}=\mathrm{C}$ - groups were from aromatic rings and alkynes bonds and responsible for compounds like alkaloid, flavonoid and terpenoids that may be act as capping and stabilizing agent for SNPs. ${ }^{20,21}$

\section{FESEM image analysis}

This analysis was carried out to measure the size and shape of the SNPs. The synthesized SNPs showed spherical form and with a size distribution ranging from $23 \mathrm{~nm}$ to $44 \mathrm{~nm}$, with average size $32.75 \mathrm{~nm}$ was found to be for SNP root (Figure 5). The SEM results are also consistent with those of $^{22}$ who reported that synthesis of SNPs from aqueous leaf extract of Phyllanthus amarus showed particle ranging between $32-53 \mathrm{~nm}$.

\section{EDS Analysis}

The EDS analysis was performed to know the percentage of silver in the sample at $3 \mathrm{KeV}$. The EDS spectra showed the different types of elements with their weight percentage such as silver $(24.72 \%)$, carbon $(38.78 \%)$, oxygen $(28.25 \%)$, chlorine $(6.37 \%)$ and calcium $(1.88 \%)$ respectively (Figure 6). In this study, the other weak signal corresponding to $\mathrm{O}_{2}$, $\mathrm{Cl}$, and $\mathrm{Ca}$ which could have derived from the plant extract and due to biomolecules bound to the surface of the SNPs. Carbon and copper peaks may be due to the presence in the grid. This was consistent with previous studies. $^{23}$

\section{XRD Characterization}

The XRD spectra were used to confirm the crystalline nature of the SNPs. The X-ray diffraction pattern of SNP was confirmed by the characteristic peak observed in XRD image. The biosynthesized SNPs by using extracts of $C$. anisata was further confirmed by the characteristic peaks observed in the XRD image at $2 \theta$ angles with minimum and maximum range at $27.64^{\circ}-76.53^{\circ}$ for SNP root (Figure 7). Here, the several Braggs reflection peak was pointed towards crystal structure of silver. The few unassigned Braggs peak might be due to capping agent stabilizing the NPs with were consistent with the earlier report. ${ }^{24}$

\section{Alpha-Amylase inhibition assay}

The SNP root extract exhibited $83.60 \%(\mathrm{P}<0.001)$ inhibition respectively at $500 \mu \mathrm{g} / \mathrm{ml}$, in which the standard percent inhibition was found to be 
85.24\% (Figure 8). The results obtained for SNP extracts of root in this study was in line with earlier report, methanolic extract of SNPs obtained from Costuspictus that showed $\mathrm{IC}_{50}$ value $534.39 \mu \mathrm{g} / \mathrm{ml}$, where a carbose showed $513.97 \mu \mathrm{g} / \mathrm{ml}^{25}$

The hallmark of DM is hyperglycemia, produced by glucose after few minutes of ingestion. The carbohydrate hydrolyzing enzymes ( $\alpha$-amylase and $\alpha$-glucosidase) are responsible for breaking $\alpha-1,4$-bonds in disaccharides and polysaccharides, thereby liberating glucose and maltose that leads to hyperglycemia. The liberated glucose diffuse to intestinal epithelial cells, where they are taken by the passive diffusion, facilitated diffusion, through transporters (GLUT) and by co-transport with other ions $\left(\mathrm{Na}^{2+}\right){ }^{26}$ The plant extract should have the ability to control glucose liberation from starch and its absorption. This may act as a therapeutic modality in the management of diabetes by reducing post prandial glucose level. ${ }^{27,28}$

\section{Glucose uptake by yeast cells}

Inhibition of glucose uptake in $5 \mathrm{mM}, 10 \mathrm{mM}$ and $25 \mathrm{mM}$ glucose concentration: Glucose transport across the yeast cell membrane was studied in an in vitro system comprising of yeast cells along with varying concentrations of glucose solution in the presence of the plant extracts. The indicator of the glucose uptake by yeast cells was the amount of glucose remained in the medium after a specific time. The glucose uptake for SNP root was found to be between $35 \%$ to $61 \%$ in $5 \mathrm{mM}$ of glucose, $42 \%$ to $70 \%$ in $10 \mathrm{mM}$ of glucose and $44 \%$ to $64 \%$ in $25 \mathrm{mM}$ of glucose concentration. The SNP extracts of root showed maximum uptake of glucose by yeast cells at $10 \mathrm{mM}$ glucose concentration with 69.51\% $(\mathrm{P}<0.001)$ (Figure 9). These extracts also showed non-linear increase in glucose uptake. Further studies are needed to validate these variations in glucose uptake by yeast cells. The significant uptake for SNP root was at $1000 \mu \mathrm{g} / \mathrm{ml}(\mathrm{P}<0.0001)$ in $10 \mathrm{mM}$ glucose concentration.

The results obtained was in accordance with another study who reported that methanolic extract of Psoralea corylifolia showed gradual increase in glucose concentration with time in external solution and decrease in concentration within the dialysis membrane. The concentration of glucose varied from $80-860 \mu \mathrm{g} / \mathrm{ml} .^{29,30}$ This may also be due to the inhibition of enzyme $\alpha$-amylase, which inhibits the release of glucose from starch, due to the high concentration of fiber, viscous polysaccharides, encapsulation of enzyme and starch that reduce its accessibility. ${ }^{30}$

\section{Glucose Diffusion Inhibitory Assay}

GDRI, an in vitro index was used to predict the effect of fibers present in the extract, which is responsible to delay the glucose absorption in gastro intestinal tract, was calculated and the results obtained were shown. The glucose movement was monitored from 30 mins to 180 mins. The rate of glucose in the dialysate was measured using standard calibration curve for known concentration of glucose. The higher GDRI index was found in the ethanolic extracts of SNP root $(78.33 \%)(\mathrm{P}<0.001)$ at $30 \mathrm{~min}$. $1 \mathrm{ml}$ of sample from dialysate was collected in intervals and glucose estimation was done by DNS method. The concentration of glucose ranges from $100 \mu \mathrm{g}$ to $600 \mu \mathrm{g} / \mathrm{ml}$ (Figure 10). This results show that the concentration of glucose inside the dialysis membrane gradually decreased due to the adsorption ability of plant extracts.

\section{Glucose Adsorption Capacity}

The glucose adsorption capacity of SNP root extracts of C. anisata at different glucose concentration ( $5 \mathrm{mM}, 10 \mathrm{mM} \& 25 \mathrm{mM}$ ) was investigated in this study and the results were presented in the.

The adsorption capacity of the extracts was found to be directly proportional to the glucose molar concentration and the glucose binding capacity was found to increase with increased molar concentration of glucose
( $5 \mathrm{mM}, 10 \mathrm{mM}$ and $25 \mathrm{mM}$ ). The rate of glucose adsorbed was calculated using standard calibration curve for known concentration of glucose (Figure 11). The SNP root extract showed $41.5 \mathrm{mMol} / \mathrm{L}(\mathrm{P}<0.0001)$ at $1000 \mu \mathrm{g} / \mathrm{ml}$. From this result it is clear that as the concentration of extract increases, the glucose adsorption capacity also increases. The dietary fibers have the ability to bind glucose and showed adsorption capacity for glucose, only when the concentration of glucose increases. ${ }^{31}$ The glucose adsorption that occurred at lower concentration of glucose $(5 \mathrm{mMol} / \mathrm{l})$, may reduce the glucose transport across the intestinal lumen, thereby reducing the postprandial hyperglycemia.

\section{Determination of antioxidant activity (DPPH assay)}

A simple reliable DPPH method was carried out to evaluate the antioxidant activity of different leaf, root, SNP leaf and SNP root extracts of $C$. anisata. The scavenging activity of the plant extracts through the annihilation of the DPPH radicals was tabulated.The SNP root extract showed maximum activity of $74.07 \%$ and standard showed $75 \%$ inhibition of scavenging activity (Figure 12). When the free radical concentration exceeds the level of antioxidant mechanism it leads to various diseases including diabetes. Free radicals or ROS generated may damage the cell through covalent binding and lipid peroxidation with leads to tissue injury. Before attacking the target biological cells, antioxidants will stabilize the free radicals. If it cannot, the ROS will induce oxidative stress that may lead to disintegration of cell membrane and cause damage to lipid, protein, DNA, which ultimately results in the development of chronic and degenerative diseases. Thus the presence of antioxidant in the plants may help to protect against the diseases they induce in biological system. The medicinal plants that have high level of antioxidants not only fight against various diseases but also act as an effective therapeutic approach for hepatic damage. 32,33

\section{CONCLUSION}

Based on the result of the present study, the SNP synthesized using the root extract of $C$. anisata showed maximum potent of antioxidant, antibacterial and hypoglycemic activities in in vitro conditionsthat may be due to the active phytoconstituents which was responsible for the activities. The extract also inhibited the alpha amylase activity which may results in delayed digestion of the dietary carbohydrates, thereby lowering the glucose liberation. The liberated glucose absorption and diffusion into circulation from the lumen is also in hibited. The maximum in vitro hypoglycemic activity of SNP root extracts was intervened by decreasing the glucose diffusion rate, increasing the glucose adsorption rate and by glucose transport across the cell membrane. The phytoconstituents of C. anisata extracts may be acting synergistically with antioxidant properties along with hypoglycemic effects in exerting an overall antidiabetic action in this study, and that should be chemically analyzed and their chemical structure should be understood in order to develop an effective diabetic therapeutic agent in future.

\section{ACKNOWLEDGEMENT MISSING}

We woulf like to thank Department of Biotechnology, Jamal Mohamed College, Tiruchirappalli, Tamilnadu and King Fahad Medical Research Centre, King Abdul Aziz University, Jeddah, SAUDI ARABIA for their support.

\section{CONFLICT OF INTERESTS}

All authors disclose no conflict of interest

\section{REFERENCES}

1. Patil R, Ahirwar B, Ahirwar D. Current status of Indian medicinal plants with antidiabetic potential: a review. Asian Pacific Journal of Tropical Biomedicine. 
2011;1(2):S291-8. http://dx.doi.org/10.1016/S2221-1691(11)60175-5.

2. Gunjan M, Ravindran M, Jana GK. A review on some potential traditional phytomedicine with antidiabetic properties. International Journal of Phytomedicine. $2011 ; 3(4): 448-58$.

3. Noor A, Bansal VS, Vijayalakshmi MA. Current update on anti-diabetic bio molecules from key traditional Indian medicinal plants. Current Science. 2013;104(6):721-7.

4. Verma L, Khatri A, Kaushik B, Patil UK, Pawar RS. Antidiabetic activity of Cassia occidentalis (Linn) in normal and alloxan-induced diabetic rats. Indian J Pharmacol. 2010;42(4):224-8. http://dx.doi.org/10.4103/0253-7613.68422 PMid:20927247 PMCid:PMC2941612.

5. Singh P, Katiyar S, Patidar D, Gupta S, Singh RK. Some Indian traditional medicinal plants with antioxidant activity: A review. International Journal of Innovative Research in Science Engineering and Technology. 2013;2(12):7303-14.

6. Bhushan MS, Rao, CHV, Ojha SK, Vijayakumar M, Verma A. An analytical re view of plants for anti diabetic activity with their phytoconstituent \& mechanism of action. International Journal of Pharmaceutical Sciences and Research. 2010;1(1):29-459.

7. Hemalatha S, Patel DK, Prasad SK, Kumar R. An overview on anti diabetic medicinal plants having insulin mimetic property. Asian Pacific Journal of Tropical Biomedicine. 2012;2(4):320-30.http://dx.doi.org/10.1016/S2221-1691(12)60032-X.

8. Hutchings, Anne, ed. Zulu medicinal plants: an inventory. University of Kwazulu Natal Press, 1996.

9. Pant G, Nayak N, Prasuna RG. Enhancement of antidandruff activity of shampoo by biosynthesized silver nanoparticles from Solanum trilobatum plant leaf Applied Nanoscience. 2012;3(5):431-439.http://dx.doi.org/10.1007/s13204-0120164-y.

10. Nikolova M, Evstatieva L, NguyenTD. Screening of plant extracts for antioxidant properties. Botanica Serbica. 2011;35(1):43-8.

11. Nair SS, Kavrekar V, Mishra A. In vitro studies on alpha amylase and alpha gluco sidase inhibitory activities of selected plant extracts. Pelagia Research Library. 2013;3(1):128-32.

12. Cirillo VP. Mechanism of glucose transport across the yeast cell membrane. J Bacteriol. 1962;84(3):485-91. PMid:14021412 PMCid:PMC277903

13. Bhutkar M, Bhise S. In vitro hypoglycemic effects of Albizzia lebbeck and Mucuna pruriens. Asian Pacific Journal of Tropical Biomedicine. 2013;3(11):866-70. http://dx.doi.org/10.1016/S2221-1691(13)60170-7.

14. Ahmed F, Siddaraju NS, Urooj A. In vitro hypoglycemic effects of Gymnema sylvestre, Tinospora cordifolia, Eugenia jambolana and Aegle marmelos. Journa of Natural Pharmaceuticals. 2011;2(2):52. http://dx.doi.org/10.4103/2229-5119. 83950.

15. Gayathri GA, Gayathri M. Preliminary qualitative phytochemical screening and in vitro hypoglycemic potential of acanthus ilicifolius and evolvulus emerginatus. International Journal of Pharmacy and Pharmaceutical Sciences. 2014;6(6):362

16. Urooj A, Sairam S. Artocarpus altilis-mode of anti-hyperglycemic activity: elucidation by suitable in-vitro and ex-vivo techniques. 2013;4(8):3013-9.

17. Daisy P, Saipriya K. Biochemical analysis of Cassia fistula aqueous extract and phytochemically synthesized gold nanoparticles as hypoglycemic treatment for diabetes mellitus. Int J Nano Medicine. 2012;7:1189-202. http://dx.doi. org/10.2147/IJN.S26650; PMid:22419867 PMCid:PMC3299574.

18. Ahmed S, Ikram S, Ahmad M, Swami BL. A review on plants extract mediated synthesis of silver nano particles for antimicrobial applications: A green expertise. Journal of Advanced Research. 2016;7(1):17-28. http://dx.doi.org/10.1016/j. jare.2015.02.007; PMid:26843966 PMCid:PMC4703479.
19. Hendre AS, Phatak RS. Sunlight induced green synthesis of silver nano particles using sundried leaves extract of Kalanchoe pinnata and evaluation of its photo catalytic potential. Der Pharmacia Letter. 2015;7(5):313-24.

20. Das P, Banerjee P, Satapathy M, Mukhopahayay A. Leaf extract mediated green synthesis of silver nano particles from widely available Indian plants: synthesis, characterization, antimicrobial property and toxicity analysis. Bio resources and Bio Processing. 2014;1(3):1-10.

21. Shameli K, Ahmad MB, Zamanian A, Sangpour P, Shabanzadeh P, Abdollahi, Y, Zargar M. Green bio synthesis of silver nano particles using Curcuma long a tuber powder. International Journal of Nano Medicine. 2012;7:5603-10.

22. Annamalai A, Babu ST, Jose NA, Sudha D, Lyza, CV. Bio synthesis and char acterization of silver and gold nano particles using aqueous leaf extraction of Phyllanthus amarus Schum. \& Thonn. World Applied Sciences Journal. 2011;13(8):1833-40.

23. Sengottaiyan A, Aravinthan A, Sudhakar C, Selvam K, Srinivasan P, Govarthanan M et al. Synthesis and characterization of Solanum nigrum-mediated silver nano particles and its protective effect on alloxan-induced diabetic rats. Journal of Nano Structure in Chemistry. 2015;6(1):41-8.

24. Malik CP, Bhati-Kushwaha, H. Biosynthesis of silver nano particles using fresh extracts of Tridax procumbens Linn. Indian journal of Experimental Biology. 2014;52:359-68

25. Aruna A, Nandhini R, Karthikeyan V, Bose P, Vijayalakshmi K. Comparative antidiabetic effect of methanolic extract of insulin plant (Costus pictus) leaves and its silver nano particle. Indo American Journal of Pharmaceutical Research. 2014;4(7):3217-30

26. Urooj A, Puttaswamy NY, Gunashekara DR, Ahmed F. Phyto chemical composition and in vitro anti-hyperglycemic potency of Eucalyptus tereticornis Bark. Indian Journal of Nutrition. 2014;1(1):1-6.

27. Picot C, Subratty AH, Mahomoodally MF. (2014). Inhibitory potential of five traditionally used native antidiabetic medicinal plants on $\alpha$-amylase, $\alpha$-glucosidase, glucose entrapment, and amylolysis kinetics in vitro. Advances in pharmacological sciences, 2014. PMid:24723945 PMCid:PMC3958646.

28. Muthuvel A, Sadhasivam G, Vitthal WM, Pachaiyappan A, Kumar M Thangavel B. In vitro antibacterial, alpha-amylase inhibition potential of three nudibranchs extracts from South East coast of India. Journal of Coastal Life Medicine. 2013;1(3):186-92.

29. Sagadevan E, Sindhu S, Suhashini R. In vitro evaluation of antidiabetic potential and phytochemical profile of Psoralea corylifolia seeds. International Journal of Pharmacognosy and Phytochemical Research. 2014;6(2):414-19.

30. Devi SG, Das MS. In vitro glucose binding activity of Terminalia bellirica. Asian J Pharm Clin Res. 2015;8(2):320-323.

31. Srichamroen $A$ Chavasit $V$. In vitro retardation of glucose diffusion with gum extracted from malva nut seeds produced in Thailand. Food Chem. 2011;127(2):45560. http://dx.doi.org/10.1016/j.foodchem.2010.12.153; PMid:23140686.

32. Khan MR, Saeed N, Shabbir M. Antioxidant activity, total phenolic and total flavonoid contents of whole plant extracts Torilis leptophylla L. BMC Complementary and Alternative Medicine. 2012;12(1):221. http://dx.doi.org/10.1186/14726882-12-221; PMid:23153304 PMCid:PMC3524761.

33. Hashim A, Kha MS, Baig MH Ahmad S. Antioxidant and alpha-Amylase Inhibitory Property of Phyllanthus virgatus L.: An in vitro and Molecular Interaction Study. Bio Med Research International. 2013:729393. PMid:23957001 PMCid:PMC3703720. 